\title{
LIBELLULA LUCRETIA.
}

\section{$0 * * * * * * * * * * * * * * * * * * * * * * * 0$}

Os maxillofum : maxillis pluribus. Antenne thorace breviores. Ala extenfæ.

Cauda (maris) hamofo-forcipata.

$$
\text { Lin. Syf. Nat. p. } 901 .
$$

CHARACTER SPECIFICUS, Ec.

LIBELLULA alis immaculatis, abdomine longiffimo.

LIBELLULA alis reticulatis, abdomine longiffimo.

$$
\begin{aligned}
& \text { Lin. Syft. Nat. Gmel. p. } 2625 \text {. } \\
& \text { Fab. Spec. inf. 1. p. } 5^{28} .
\end{aligned}
$$

LIBELLULA LUCRETIA.

$$
\text { Drury inf. 2. p. 87. t. } 48 \text {. f. } 1 .
$$

In elegantiffimo opere Domini Drury de Infectis exoticis primum depicta eft hæc Libellulæ fpecies. Caffrariam? incolit, et magnitudine vera in tabula exprimitur. 


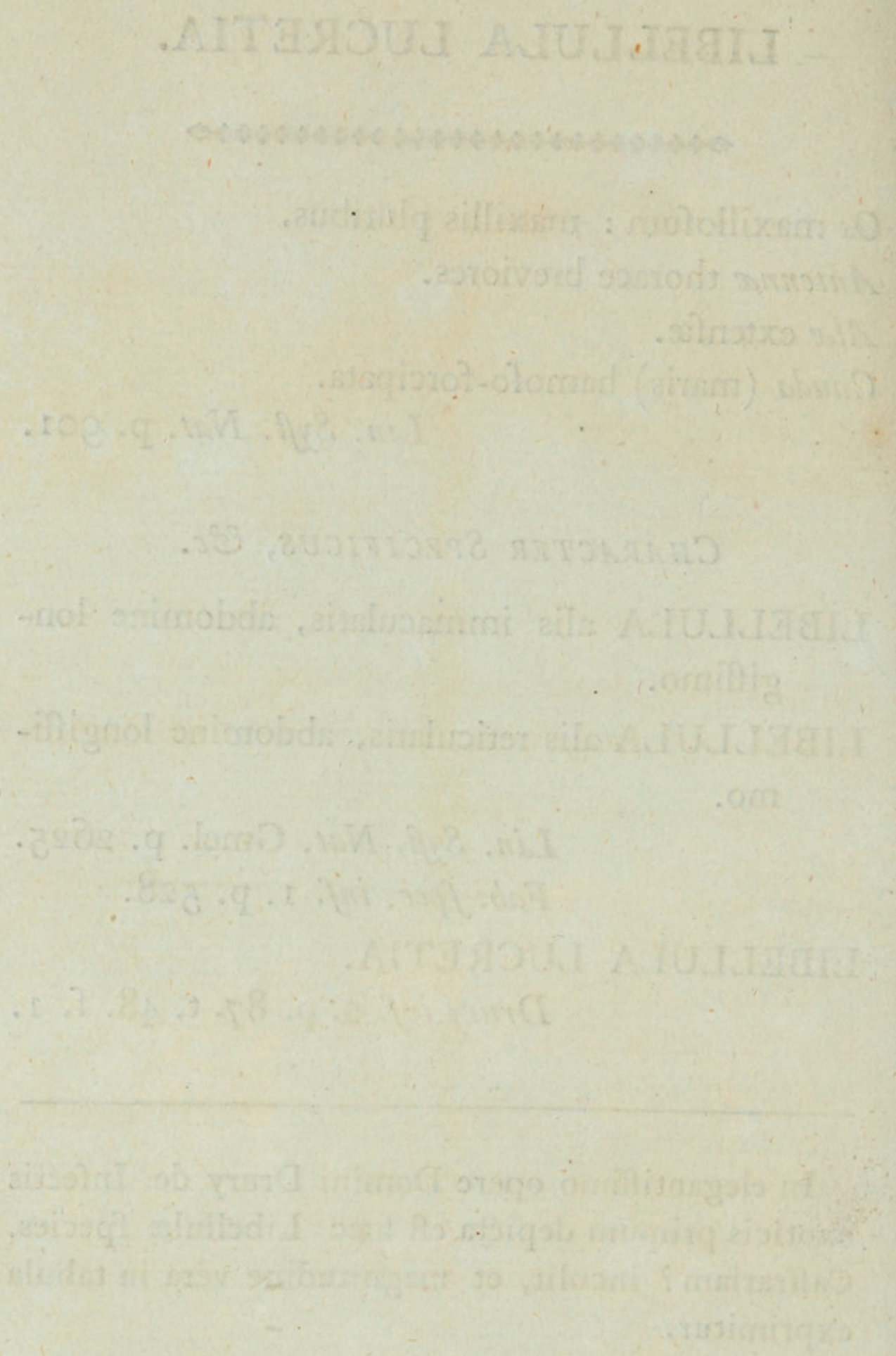




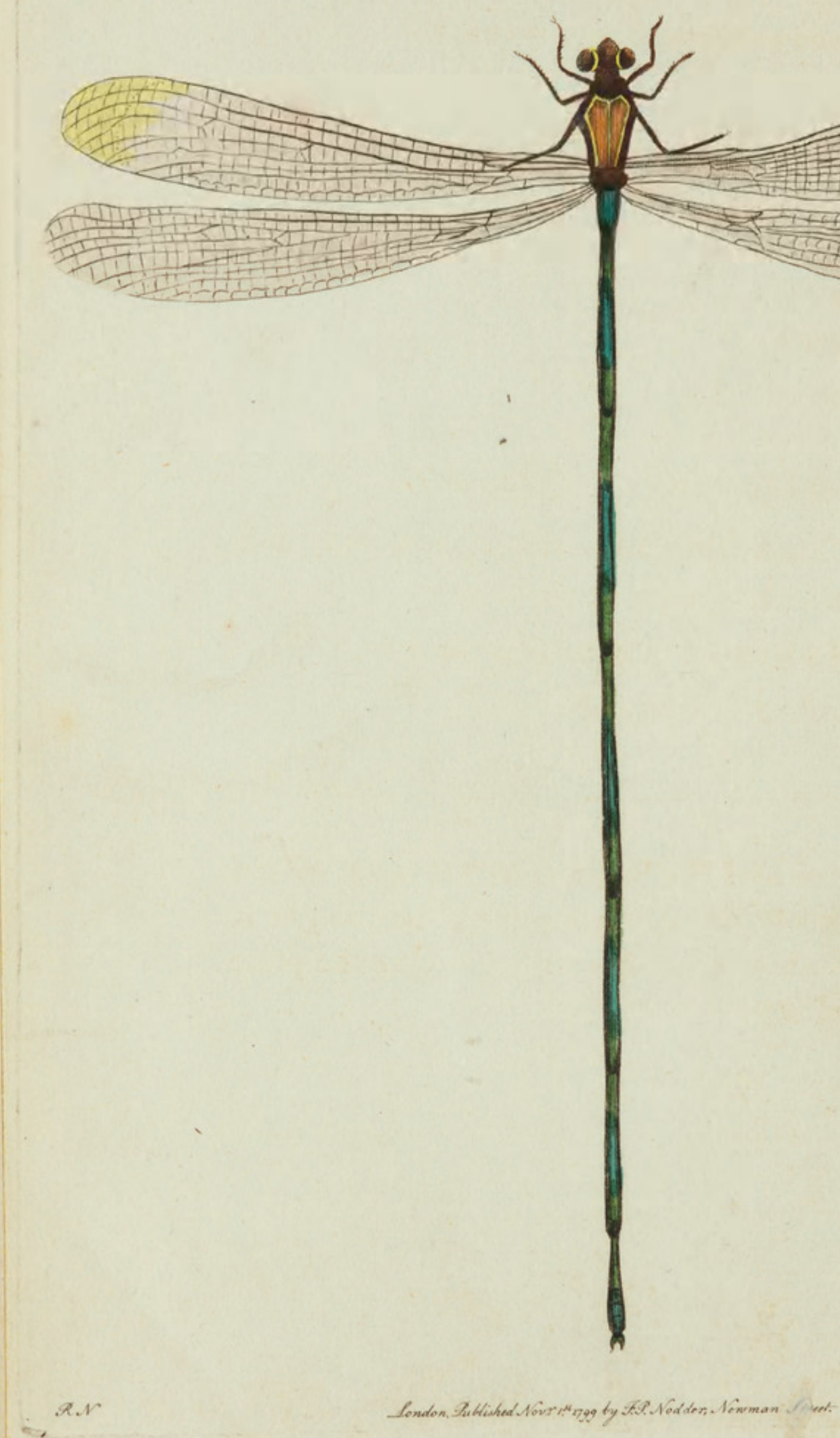


TH E

\section{LINEAR LIBELLULA.}

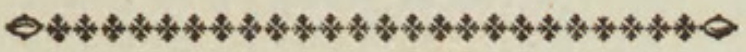

\section{GENERIC CHARACTER.}

Mouth confifting of feveral mandibles.

Antenna very flender, filiform, fhorter than the thorax.

Wings fpreading.

Abdomen lengthened.

\section{SPECIFIC CHARACTER, छिC.}

LIBELLULA with plain reticulated wings, and extremely long abdomen.

The linear LIBELLULA or Dragon-Fly. The long-bodied DRAGON-FLY.

This fpecies of Libellula was firt figured in the elegant work of Mr. Drury on exotic infects; it is a native of Caffraria? and is reprefented on the plate in its natural fize. 


\section{$2 \mathrm{BHL}$ Biodiversity Heritage Library}

Shaw, George. 1799. "The Linear Libellula, Libellula lucretia [PI. 407]." The Naturalist's Miscellany 11(CXXIII), https://doi.org/10.5962/p.310854.

View This Item Online: https://www.biodiversitylibrary.org/item/276496

DOI: https://doi.org/10.5962/p.310854

Permalink: https://www.biodiversitylibrary.org/partpdf/310854

\section{Holding Institution}

Museums Victoria

\section{Sponsored by}

Atlas of Living Australia

\section{Copyright \& Reuse}

Copyright Status: Public domain. The BHL considers that this work is no longer under copyright protection.

This document was created from content at the Biodiversity Heritage Library, the world's largest open access digital library for biodiversity literature and archives. Visit BHL at https://www.biodiversitylibrary.org. 